Site-dependent $\mathrm{N}$ uptake from $\mathrm{N}$-form mixtures by arctic plants, soil microbes and ectomycorrhizal fungi

Clemmensen, Karina Engelbrecht; Sørensen, Pernille Lærkedal; Michelsen, Anders; Jonasson, Sven Evert; Ström, Lena

Published in:

Oecologia

DOI:

10.1007/s00442-008-0962-9

Publication date:

2008

Document version

Publisher's PDF, also known as Version of record

Citation for published version (APA):

Clemmensen, K. E., Sørensen, P. L., Michelsen, A., Jonasson, S. E., \& Ström, L. (2008). Site-dependent N uptake from $\mathrm{N}$-form mixtures by arctic plants, soil microbes and ectomycorrhizal fungi. Oecologia, 155, 771-783. https://doi.org/10.1007/s00442-008-0962-9 


\title{
Site-dependent $\mathbf{N}$ uptake from $\mathbf{N}$-form mixtures by arctic plants, soil microbes and ectomycorrhizal fungi
}

\author{
Karina Engelbrecht Clemmensen - Pernille Lærkedal Sorensen • \\ Anders Michelsen · Sven Jonasson · Lena Ström
}

Received: 8 March 2007 / Accepted: 7 January 2008/Published online: 2 February 2008

(C) Springer-Verlag 2008

\begin{abstract}
Soil microbes constitute an important control on nitrogen $(\mathrm{N})$ turnover and retention in arctic ecosystems where $\mathrm{N}$ availability is the main constraint on primary production. Ectomycorrhizal (ECM) symbioses may facilitate plant competition for the specific $\mathrm{N}$ pools available in various arctic ecosystems. We report here our study on the $\mathrm{N}$ uptake patterns of coexisting plants and microbes at two tundra sites with contrasting dominance of the circumpolar ECM shrub Betula nana. We added equimolar mixtures of glycine- $\mathrm{N}, \mathrm{NH}_{4}^{+}-\mathrm{N}$ and $\mathrm{NO}_{3}^{-}-\mathrm{N}$, with one $\mathrm{N}$ form labelled with ${ }^{15} \mathrm{~N}$ at a time, and in the case of glycine, also labelled with ${ }^{13} \mathrm{C}$, either directly to the soil or to ECM fungal ingrowth bags. After 2 days, the vegetation contained 5.6, 7.7 and $9.1 \%$ (heath tundra) and 7.1, 14.3 and $12.5 \%$ (shrub tundra) of the glycine-, $\mathrm{NH}_{4}^{+}$- and $\mathrm{NO}_{3}^{-}-{ }^{15} \mathrm{~N}$, respectively, recovered in the plant-soil system, and the major part of ${ }^{15} \mathrm{~N}$ in the soil was immobilized by microbes (chloroform fumigation-extraction). In the subsequent 24 days, microbial $\mathrm{N}$ turnover transferred about half of the immobilized ${ }^{15} \mathrm{~N}$ to the non-extractable soil organic $\mathrm{N}$ pool,
\end{abstract}

Communicated by Hakan Wallander.

Electronic supplementary material The online version of this article (doi:10.1007/s00442-008-0962-9) contains supplementary material, which is available to authorized users.

K. E. Clemmensen $(\bowtie) \cdot$ P. L. Sorensen · A. Michelsen ·

S. Jonasson

Department of Terrestrial Ecology, Institute of Biology,

University of Copenhagen, Øster Farimagsgade 2D,

1353 Copenhagen K, Denmark

e-mail: karinac@bi.ku.dk

L. Ström

GeoBiosphere Science Centre, Physical Geography

and Ecosystems Analysis, Lund University, Sölvegatan 12,

22362 Lund, Sweden demonstrating that soil microbes played a major role in $\mathrm{N}$ turnover and retention in both tundra types. The ECM mycelial communities at the two tundras differed in $\mathrm{N}$ form preferences, with a higher contribution of glycine to total $\mathrm{N}$ uptake at the heath tundra; however, the ECM mycelial communities at both sites strongly discriminated against $\mathrm{NO}_{3}^{-}$. Betula nana did not directly reflect ECM mycelial $\mathrm{N}$ uptake, and we conclude that $\mathrm{N}$ uptake by ECM plants is modulated by the $\mathrm{N}$ uptake patterns of both fungal and plant components of the symbiosis and by competitive interactions in the soil. Our field study furthermore showed that intact free amino acids are potentially important $\mathrm{N}$ sources for arctic ECM fungi and plants as well as for soil microorganisms.

Keywords Betula nana (dwarf birch) $\cdot{ }^{13} \mathrm{C}$. Microbial biomass $\cdot$ Mycelial ingrowth bags $\cdot{ }^{15} \mathrm{~N}$

\section{Introduction}

Soil microbial biomass may constitute an important control on nutrient availability, turnover and retention in many ecosystems where nitrogen $(\mathrm{N})$ availability is the main constraint on primary production and the proportion of microbial to plant biomass $\mathrm{N}$ is high (Jonasson et al. 1999; Lipson et al. 1999; Grogan and Jonasson 2003). Several studies have shown a large initial microbial immobilization of $\mathrm{N}$ added to nutrient-deficient soils in arctic and alpine tundra (Schimel and Chapin 1996; Grogan and Jonasson 2003; Nordin et al. 2004) and in boreal and temperate forest (Näsholm et al. 1998; McFarland et al. 2002; Finzi and Berthrong 2005). The high microbial $\mathrm{N}$ sequestration in these studies was irrespective of whether the added $\mathrm{N}$ was in amino acid, $\mathrm{NH}_{4}^{+}$or $\mathrm{NO}_{3}^{-}$form. Short-term 
microbial immobilization of added $\mathrm{N}$, however, did not appear to lead to longer term increases of $\mathrm{N}$ bound in microbial biomass (Fisk and Schmidt 1996). A slow accumulation of $\mathrm{N}$ in plants has been observed in a few longer term studies over weeks to months (Schimel and Chapin 1996; McFarland et al. 2002; Grogan and Jonasson 2003). This accumulation was considered to be a likely consequence of the uptake of microbial re-cycled N (Kaye and Hart 1997; Hodge et al. 2000), but given the apparently superior competitive abilities of soil microbes, the mechanisms behind plant access to adequate amounts of nutrients for annual growth are still poorly understood (Schimel and Bennett 2004; Jones et al. 2005a).

The growing body of evidence on plant uptake capacity for low-molecular organic N (Kielland 1994; Näsholm et al. 1998; Svennerstam et al. 2007) demonstrates that many plants can short-circuit the microbial mineralization step and - to some degree-compete with the microbes for free amino acids that are often equally abundant as $\mathrm{NH}_{4}^{+}$ and $\mathrm{NO}_{3}^{-}$in organogenic soils (Nordin et al. 2004). It has been suggested that differences in microbial and plant uptake capacities for specific $\mathrm{N}$ compounds may be complementary and, thus, provide specialized niches for coexisting plants and microbes (Lipson and Näsholm 2001). In northern ecosystems, the presence of mycorrhizal symbioses in most plant species complicates the studies of pathways for nutrient partitioning between plants and soil microbes (Lindahl et al. 2002). The most abundant mycorrhizal symbioses in arctic ecosystems are ericoid mycorrhiza (ERM) in ericoid dwarf shrubs and ectomycorrhiza (ECM) in shrubs and herbs belonging to the genera Salix, Betula, Alnus, Dryas, Polygonum and Kobresia (Michelsen et al. 1998; Clemmensen and Michelsen 2006). Most of the ERM and ECM fungal species release exo-enzymes to hydrolyse $\mathrm{N}$ from more complex organic molecules, such as chitin and protein (Leake and Read 1997), and possess cell membrane transporters for oligopeptides and amino acids as well as for $\mathrm{NH}_{4}^{+}$and $\mathrm{NO}_{3}^{-}$ (Smith and Read 1997; Benjdia et al. 2006). Thus, plants with ERM and ECM mycorrhizal associations have a clear advantage over non-mycorrhizal plants in terms of being able to access $\mathrm{N}$. This advantage is particularly pronounced in ecosystems where most of the $\mathrm{N}$ originates from decaying microorganisms and plant material and enters the soil in complex forms, such as protein (Weintraub and Schimel 2005) or chitin (Gooday 1990).

In comparison with ERM fungi, ECM fungi generally have a more widely distributed network of external mycelium extending from the mycorrhizal structures on the root tips and forming about $75 \%$ of the absorptive surface area in ECM plant roots (Smith and Read 1997; Simard and Durall 2004). Their comparable growth pattern, physiology, small size, high surface-volume ratio and rapid growth rates allow ECM fungi to compete strongly with saprotrophic fungi for limiting soil nutrients throughout the heterogeneous soil environment (Leake et al. 2002). The timing of ECM fungal transport of $\mathrm{N}$ to plants, however, may depend on the strengths of both the mycelial and plant sinks (Simard and Durall 2004), and N retention within the hyphal network may partly explain slow plant accumulation of added $\mathrm{N}$ in nutrient-deficient ecosystems (Aber et al. 1998). Furthermore, the abilities to access different inorganic and organic $\mathrm{N}$ pools differ among the large number of ECM fungal species (Leake and Read 1997), and associations with different ECM fungal communities in different ecosystem types may facilitate the broad ecological amplitudes observed in some ECM plant species (van der Heijden and Vosatka 1999). Thus, more focus on mycorrhizal $\mathrm{N}$ uptake patterns is needed to understand plant-microbial $\mathrm{N}$ partitioning in ecosystems where mycorrhizal plants dominate the vegetation (Chalot and Brun 1998).

In the study reported here, we explored soil microbial and plant $\mathrm{N}$ uptake throughout the growing season at two subarctic tundra sites of contrasting soil nutrient availability and abundance of the ECM shrub Betula nana. At both sites, we measured soil pools of total dissolved $\mathrm{N}$ (TDN), amino acids, $\mathrm{NH}_{4}^{+}$and $\mathrm{NO}_{3}^{-}$and performed ${ }^{15} \mathrm{~N}$ tracer studies in which three main aspects were varied in a factorial design: ${ }^{15} \mathrm{~N}$ form added (glycine, $\mathrm{NH}_{4}^{+}$or $\mathrm{NO}_{3}$ ), duration of ${ }^{15} \mathrm{~N}$ incubation (48 h or 26 days) and method of ${ }^{15} \mathrm{~N}$ addition $\left({ }^{15} \mathrm{~N}\right.$ added to soil or to ECM mycelial ingrowth bags). We hypothesized: (1) that microbes would be superior competitors in the short term but that plants would access part of the added $\mathrm{N}$ in the longer term; (2) that the availability of different $\mathrm{N}$ forms at the two sites would, at least partly, explain $\mathrm{N}$ uptake patterns in plants; (3) that the ECM B. nana would access different proportions of the three $\mathrm{N}$ forms at the two sites as a consequence of an association with ECM fungal communities with sitedependent $\mathrm{N}$-form preferences.

\section{Material and methods}

\section{Study sites}

The study was conducted during the summer of 2003 at two treeless tundra sites located just below the forest line near Abisko in Northern Sweden. Based on vegetation characteristics, the two sites, designated heath and shrub tundra, respectively, were chosen to represent different soil nutrient availability levels. The heath tundra was located approximately $0.5 \mathrm{~km}$ south of Abisko on the upper part of a gentle eastward-facing slope $\left(68^{\circ} 20,786^{\prime} \mathrm{N}, 18^{\circ} 49,515^{\prime} \mathrm{E}\right.$; approx. $415 \mathrm{~m}$ a.s.l.). The organic layer was about $10 \mathrm{~cm}$ 
Table 1 Soil characteristics of heath and shrub tundra sites near Abisko in subarctic Swedish Lapland

\begin{tabular}{lllllll}
\hline Site & $\begin{array}{l}\text { Soil depth } \\
\text { sampled }(\mathrm{cm})\end{array}$ & $\begin{array}{l}\text { Bulk density } \\
\left(\mathrm{mg} \mathrm{DM} \mathrm{cm}{ }^{-3}\right)\end{array}$ & $\begin{array}{l}\text { SOM } \\
(\% \text { of DM })\end{array}$ & $\begin{array}{l}\text { N concentration } \\
(\% \text { of DM })\end{array}$ & \multicolumn{2}{c}{$\begin{array}{l}\text { Soil moisture }(\% \text { of DM }) \\
\text { July }\end{array}$} \\
\hline Heath tundra & 10 & $94.5 \pm 7.8 \mathrm{a}$ & $90.4 \pm 1.2$ & $1.55 \pm 0.05 \mathrm{a}$ & $241 \pm 19 \mathrm{~b}$ & $194 \pm 9 \mathrm{~b}$ \\
Shrub tundra & 15 & $29.7 \pm 2.3 \mathrm{~b}$ & $91.4 \pm 1.3$ & $1.13 \pm 0.06 \mathrm{~b}$ & $563 \pm 43 \mathrm{a}$ & $525 \pm 37 \mathrm{a}$ \\
\hline
\end{tabular}

DM, Dry mass; SOM, soil organic matter

All values are given as means \pm standard error

Values followed by different letters within a column indicate a significant $(P<0.05)$ difference between sites

deep, well drained and resting on rocky mineral soil (Table 1). The vegetation was up to $15 \mathrm{~cm}$ high and dominated by ericoid dwarf shrubs, mainly Vaccinium $u$ liginosum L., Andromeda polifolia L. and Empetrum hermaphroditum Hagerup, and with low-statured Betula nana L. and herbs, mainly Carex spp., Equisetum spp., Tofieldia pusilla (Michx) Pers., Silene acaulis (L.) Jacq. and Astragalus frigidus (L.) A., as sub-dominants [Electronic Supplementary Material (ESM) S1]. The shrub tundra was located approximately $2 \mathrm{~km} \mathrm{SE}$ of Abisko in a northward-facing, sloping depression $\left(68^{\circ} 20,511^{\prime} \mathrm{N}\right.$, $18^{\circ} 50,562^{\prime} \mathrm{E}$; approx. $415-422 \mathrm{~m}$ a.s.l.). The soil had a loose, moist, 15- to 50-cm-deep organic horizon (Table 1), and there were small tracks with running water between tussocks in the lowest part of the depression. This site was equally dominated by ericoid dwarf shrubs (the same species as at the heath) and deciduous shrubs (B. nana and occasional Salix spp.), the latter forming an up to 50-cmhigh canopy layer. The most common herbs were Equisetum spp. and Carex spp. In the bottom layer, moss covered most of the ground, at the heath along with occasional lichens.

The climate is subarctic, with mean summer and winter temperatures of 10 and $-9^{\circ} \mathrm{C}$, respectively, and with an annual precipitation of approximately $300 \mathrm{~mm}$ of which one-third falls as summer precipitation. The snow-free season usually lasts from late May to early October (Royal Swedish Academy of Sciences, Abisko Scientific Research Station, http://www.ans.kiruna.se/ans.htm).

\section{Setup of labelling experiment}

On 18-23 June, six approximately $20-\mathrm{m}^{2}$ replicate blocks of similar vegetation were established at each site. Thirteen separate plots of $0.2 \times 0.2 \mathrm{~m}$ each, including the rooting point of at least one $B$. nana ramet, were selected within each block and were randomly assigned to one of 12 treatment combinations (see below) or as an untreated control. The distance between individual plots was 1-3 m. Cylindrical fungal ingrowth bags (Wallander et al. 2001), approximately $8 \mathrm{~cm}$ high and $4 \mathrm{~cm}$ in diameter, constructed of nylon mesh $(50-\mu \mathrm{m}$ mesh size; Sintab, Sweden) and filled with approximately $120 \mathrm{~g}$ acid-washed sand were placed in half of the treatment and the control plots. In each plot, five bags were inserted vertically with the upper end level with the organic soil surface. One bag was placed in the centre of the $0.2 \times 0.2-\mathrm{m}$ plot, and one was placed in the centre of each of the four $0.1 \times 0.1-\mathrm{m}$ sub-squares. The surface litter and moss layer was replaced over the bags, which were left for fungal ingrowth during the following month.

On 18 and 22 July, the heath and shrub tundra soils were isotopically labelled to investigate $\mathrm{N}$ uptake in plants and microbes. We added three different ${ }^{15} \mathrm{~N}$ forms, either directly to the soil or to the ingrowth bags, and incubated the soils for either 2 or 26 days before harvest (i.e. at each site, a $3 \times 2 \times 2$ factorial design with $n=6$ ). The three $\mathrm{N}$ forms (glycine, $\mathrm{NH}_{4}^{+}$and $\mathrm{NO}_{3}^{-}$) were combined in mixtures to make up equal proportions of $\mathrm{N}$, and one $\mathrm{N}$ form was labelled with ${ }^{15} \mathrm{~N}$ at a time, with glycine also labelled with ${ }^{13} \mathrm{C}$ (Nordin et al. 2001). The ${ }^{15} \mathrm{~N}$ compounds were $\mathrm{U}-{ }^{13} \mathrm{C}-{ }^{15} \mathrm{~N}$-glycine $\left({ }^{15} \mathrm{~N}, 96-99\right.$ atom\%; ${ }^{13} \mathrm{C}, 98$ atom\%; Cambridge Isotope Laboratory, Andover, MA), ${ }^{15} \mathrm{NH}_{4} \mathrm{Cl}$ (98 atom\%) and $\mathrm{K}^{15} \mathrm{NO}_{3}$ (98 atom\%). The mixtures were distributed in five points in each treatment plot, corresponding to the positions of the ingrowth bags, by inserting a syringe to a depth of $5 \mathrm{~cm}$ in the soil or the bags and pulling it up as the solution was dispensed. Nitrogen was added at rates equivalent to $390 \mathrm{mg} \mathrm{N} \mathrm{m}^{-2}$, including $136 \mathrm{mg}{ }^{15} \mathrm{~N} \mathrm{~m}^{-2}$. The $\mathrm{N}$ mixtures were added as a $20 \mathrm{ml}$ solution $\left(54.4 \mathrm{mM}{ }^{15} \mathrm{~N}\right)$ to each of the five points in soilinjected plots and $5 \mathrm{ml}$ of a more concentrated solution $\left(217.6 \mathrm{mM}{ }^{15} \mathrm{~N}\right)$ to each point in bag-injected plots.

\section{Sample processing}

Labelled plots were harvested after 2 and 26 days. The five ingrowth bags per plot were retrieved and the contents combined to make up one sample. The entire $20 \times 20-\mathrm{cm}$ plots were cut out to a depth of 10 and $15 \mathrm{~cm}$ below the soil surface at the heath and shrub tundra, respectively, and all vegetation rooted within the plot was included. 
Unlabelled control plots were harvested in the same way on 21-23 August. A set of soils for supplementary analyses of nutrient concentrations was sampled on 18 July by harvesting six $10 \times 10-\mathrm{cm}$ soil cores at random positions at each site. All samples were kept in separate plastic bags at $+2{ }^{\circ} \mathrm{C}$ until sorted. Sample processing was completed within 2-3 days.

The individuals of $B$. nana were carefully sorted out of the sample in intact form, whereas the rest of the vegetation was cut at the soil surface and pooled as aboveground plant material. Betula nana was separated into leaves, stems + coarse roots and fine roots; the latter represented the nonwoody part of the root system, less than $0.5 \mathrm{~mm}$ in diameter. The remaining sample of organic soil, including roots and rhizomes of unseparated species, was homogenized by cutting the soil in approximately $2 \times 2 \times 2$-cm cubes. Roots and rhizomes were sorted out of 20-30 randomly chosen cubes to obtain an approximately 50-g sample of fresh soil and a subsample of belowground plant biomass. All plant samples were immersed in several baths of $0.5 \mathrm{mM} \mathrm{CaCl}_{2}$ to remove any adhering ${ }^{15} \mathrm{~N}$ label from the exterior surfaces. The plant samples and the remaining unsorted bulk soil samples were dried at $70^{\circ} \mathrm{C}$ for $48 \mathrm{~h}$. The sand from the ingrowth bags was extracted in water, and mycelium floating in the water phase was collected on a nylon mesh and freeze-dried.

\section{Soil analyses}

Fresh soil samples were mixed thoroughly, and a 10-g subsample was used to determine soil moisture as mass loss after freeze-drying and soil organic matter (SOM) content as loss on ignition at $660^{\circ} \mathrm{C}$ for $6 \mathrm{~h}$. A $10 \mathrm{~g}$ subsample was extracted with $50 \mathrm{ml} 0.1 \mathrm{M} \mathrm{K}_{2} \mathrm{SO}_{4}$ (for control soils only: another $10 \mathrm{~g}$ with $50 \mathrm{ml}$ demineralized water was used for amino acid analysis) for $1 \mathrm{~h}$ and filtered through glass fibre filters (Whatman GF/D; 2.7- $\mu \mathrm{m}$ mesh size). Another $10 \mathrm{~g}$ fresh soil was fumigated with chloroform for $24 \mathrm{~h}$ to release $\mathrm{C}$ and $\mathrm{N}$ fixed in the microbial biomass before extraction with $\mathrm{K}_{2} \mathrm{SO}_{4}$ (Brookes et al. 1985). The extracts were kept frozen until further analyses.

Organic $\mathrm{C}$ in the fumigated and nonfumigated extracts was determined on a total organic $\mathrm{C}$ analyser (Schimadzu 5000A, Kyoto, Japan), and total $\mathrm{N}$ was determined after persulfate digestion (Zhou et al. 2003) followed by the analysis of $\mathrm{NO}_{3}^{-}-\mathrm{N}$ using an autoanalyser (Fiastar 5000, Foss Tecator, Sweden). Dissolved total N (DTN) was measured as the $\mathrm{N}$ content of digested nonfumigated extracts, i.e. soluble organic $\mathrm{N}$ plus inorganic N. Microbial biomass $\mathrm{C}$ and $\mathrm{N}$ pools were calculated as the differences between fumigated and nonfumigated extracts (Brookes et al. 1985; Vance et al. 1987). We used extractability factors of $k_{\mathrm{EC}}=0.45$ and $k_{\mathrm{EN}}=0.40$ to account for the microbial biomass $\mathrm{C}$ and $\mathrm{N}$ pools that were not chloroformlabile (Schmidt et al. 2002).

In control soils, $\mathrm{NH}_{4}^{+}-\mathrm{N}$ and $\mathrm{NO}_{3}^{-}-\mathrm{N}$ pools were analysed in $\mathrm{K}_{2} \mathrm{SO}_{4}$ and water extracts. Amino acid concentrations were analysed in water extracts using an ion chromatography system from Dionex, equipped with electrochemical detection with a gold amperometry cell and the analytical column AminoPac PA10. Fungal biomass was estimated in freeze-dried, ground soil (approx. $0.3 \mathrm{~g}$ ) by the ergosterol assay (Nylund and Wallander 1992) as modified by Clemmensen et al. (2006). Ergosterol was quantified on a reverse-phase high-performance liquid chromatography (HPLC) system with UV detection at $282 \mathrm{~nm}$. Fungal biomass $\mathrm{C}$ was estimated using conversion factors of $3.5 \mu \mathrm{g}$ ergosterol and $430 \mu \mathrm{g} \mathrm{C} \mathrm{mg}^{-1}$ fungal biomass (Salmanowicz and Nylund 1988; Montgomery et al. 2000).

${ }^{15} \mathrm{~N}$ and ${ }^{13} \mathrm{C}$ isotopic analyses

Dried plant and soil samples were ground to a fine powder, and isotopic ${ }^{13} \mathrm{C}:{ }^{12} \mathrm{C}$ and ${ }^{15} \mathrm{~N}:{ }^{14} \mathrm{~N}$ ratios and $\mathrm{C}$ and $\mathrm{N}$ concentrations were analysed on an isotope ratio mass spectrometer (IRMS; Isoprime, Micromass-GV Instruments) coupled to a Eurovector $\mathrm{CN}$ elemental analyser. The mycelia from the ingrowth bags were rinsed under a dissection microscope for removal of organic particles that contaminated samples under bag recovery, while sand particles (containing no $\mathrm{C}$ or $\mathrm{N}$ ) were left in the samples analysed on the IRMS. Mycelial biomass was estimated from measured $\mathrm{C}$ mass by assuming $400 \mu \mathrm{g} \mathrm{C} \mathrm{mg}^{-1}$ mycelium (Clemmensen et al. 2006).

Microbial ${ }^{15} \mathrm{~N}$ atom\% was determined using the acidtrap diffusion technique on digested extracts (Stark and Hart 1996). Five millilitres of fumigated digests or $10 \mathrm{ml}$ nonfumigated digests were transferred to $60 \mathrm{ml}$ HDPE bottles, and nonfumigated samples were spiked with $70 \mu \mathrm{g}$ $\mathrm{N}$ of known ${ }^{15} \mathrm{~N}:{ }^{14} \mathrm{~N}$ ratio to increase the total $\mathrm{N}$ contents to the optimum of $100-150 \mu \mathrm{g} N$ required for the IRMS analyses. Devarda's Alloy (0.4 g) was added per $10 \mathrm{ml}$ of sample to reduce $\mathrm{NO}_{3}^{-}-\mathrm{N}$ to $\mathrm{NH}_{4}^{+}-\mathrm{N}$, and $0.75 \mathrm{~g} \mathrm{KCl}$ per $10 \mathrm{ml}$ of sample was added to increase the ionic strength of the digests. In order to raise the $\mathrm{pH}$ of the samples to above 13 , we added $5 \mathrm{M} \mathrm{NaOH}$ ( $1 \mathrm{ml}$ per $10 \mathrm{ml}$ of sample), and the bottles were immediately sealed with a cap suspending an acidified $\left(15 \mu \mathrm{l} 1.5 \mathrm{M} \mathrm{H}_{2} \mathrm{SO}_{4}\right)$ quartz filter paper disc over the solution. The samples were incubated for 4 days on a shaking table at $50 \mathrm{rpm}$ to trap all volatilized $\mathrm{NH}_{3}$ on the filter papers, which subsequently were dried in a desiccator and analysed on the IRMS. Standards of known atom $\%{ }^{15} \mathrm{~N}$ included throughout the procedure showed 
$75-100 \%$ recovery of $\mathrm{N}$. Microbial ${ }^{13} \mathrm{C}$ atom $\%$ in control and glycine-labelled soils was determined by freeze-drying of fumigated and nonfumigated $\mathrm{K}_{2} \mathrm{SO}_{4}$ extracts (Ryan and Aravena 1994). The freeze-dried volumes were kept as low as possible $(0.250 \mathrm{ml}$ of fumigated and $1 \mathrm{ml}$ of nonfumigated extracts, corresponding to $25-100 \mu \mathrm{g} \mathrm{C}$ ) to avoid the interference of salt with the IRMS analysis. Isotopic ratios were corrected for the isotopic pool dilutions caused by blank contamination and spiking.

Atom\% enrichment for each component was determined by subtracting the natural ${ }^{13} \mathrm{C}$ or ${ }^{15} \mathrm{~N}$ abundance of the control samples from the atom\% of the labelled samples. Control values for each pool were averaged within each site. The percentage of label recovered in a particular pool was determined by multiplying the ${ }^{13} \mathrm{C}$ or ${ }^{15} \mathrm{~N}$ atom $\%$ enrichment of the pool by the pool size and dividing this value by the amount of label added; for example, for $\mathrm{N}$ : (atom $\%{ }^{15} \mathrm{~N}_{\text {labelled }}-$ atom $\%{ }^{15} \mathrm{~N}_{\text {control }}$ ) $\times \mathrm{N}$ pool size/total added ${ }^{15} \mathrm{~N}$.

Total ecosystem ${ }^{15} \mathrm{~N}$ recovery, defined as the sum of ${ }^{15} \mathrm{~N}$ recovery in the two complementary pools, bulk soil and total plant biomass, ranged between 40 and $110 \%$ in soil-injected plots and between 20 and $100 \%$ in baginjected plots (ESM S2). This estimate of total ecosystem ${ }^{15} \mathrm{~N}$ recovery is independent of uncertainties in extractability of microbial biomass ${ }^{15} \mathrm{~N}$, unlike earlier studies of Schimel and Chapin (1996) and Grogan and Jonasson (2003). To explore the proportional partitioning of ${ }^{15} \mathrm{~N}$ into major ecosystem pools, the total ecosystem ${ }^{15} \mathrm{~N}$ recovery of each plot was set to $100 \%$, and ${ }^{15} \mathrm{~N}$ recovery in each pool was rescaled proportionally before mean recoveries were calculated. This rescaling assumes that the relative recovery of ${ }^{15} \mathrm{~N}$ is representative of the movement of $\mathrm{N}$ from the added $\mathrm{N}$ form independently of whether the isotope was under- or over-recovered (Finzi and Berthrong 2005).

\section{Statistical analyses}

Data means were compared using analyses of variance (ANOVAs) with type III sums of squares by the GLM procedure, with significant differences evaluated by $\mathrm{Tu}$ key's HSD multiple comparison of means test (SAS Institute v8.02, 2001; SAS Institute, Cary, NC). Results with $P<0.05$ were regarded as statistically significant, although marginally significant $(P<0.10)$ results are also reported. Pool sizes in control soils were analysed with two-factor ANOVAs including site and date as main factors (all samples were taken from separate plots). For each labelling method, treatment effects were analysed with three-factor ANOVAs including site, incubation period and $\mathrm{N}$ treatment as main factors. For each site and incubation period, treatment means were compared with one-factor ANOVAs. All multi-factor models were fully factorial. Block was included in models whenever the block effect was below $P=0.20$ to account for any underlying gradients at the sites not related to the treatments. Prior to performing the ANOVAs, we analysed the data for homogeneity of variances with Levene's test and, if necessary, carried out the appropriate root- or logtransformations.

The relationship between ${ }^{13} \mathrm{C}$ and ${ }^{15} \mathrm{~N}$ enrichment in microbial biomass, mycelia and plant fractions from the U- ${ }^{13} \mathrm{C}-{ }^{15} \mathrm{~N}$-glycine treatment was tested with simple linear regressions for each site and time period separately. There were no effects of labelling method (i.e. soil vs. bag injection) on microbial biomass regressions, and data from the two methods were pooled. Regression slopes were compared using two-tailed $t$ tests. A conservative estimate of the fraction of ${ }^{15} \mathrm{~N}$ taken up as intact glycine was obtained by dividing the slopes of the regression lines with a slope of 2 , the ${ }^{13} \mathrm{C}:{ }^{15} \mathrm{~N}$ ratio of the added glycine (Näsholm et al. 1998).

\section{Results}

\section{Soil $\mathrm{C}$ and $\mathrm{N}$ pools}

The SOM content on a mass basis was similar at the two sites, whereas soil bulk density was much lower at the more moist shrub tundra site (Table 1). Soil microbial biomass $\mathrm{C}$ and $\mathrm{N}$ concentrations were lower at the heath than at the shrub site, whereas fungal biomass $\mathrm{C}$ was higher, indicating that fungi dominated the microbial biomass more at the heath tundra (Table 2).

The concentrations of soluble soil $\mathrm{C}$ and $\mathrm{N}$ fractions were significantly, or for amino acids non-significantly, higher at the shrub tundra than at the heath tundra, except for the $\mathrm{NO}_{3}^{-}$concentration, which was marginally significantly higher at the heath tundra (Table 2). The concentration of DTN at the shrub tundra, 91-98 $\mu \mathrm{g} \mathrm{g}^{-1}$ DM soil, was about twofold higher than that at the heath tundra, 43-55 $\mu \mathrm{g} \mathrm{g}^{-1} \mathrm{DM}$ soil (Table 2). Generally, $\mathrm{NH}_{4}^{+}-$ $\mathrm{N}$ made up approximately $75 \%\left(1.4-4.5 \mu \mathrm{g} \mathrm{g}^{-1} \mathrm{DM}\right)$ of the total available $\mathrm{N}$ and amino acids approximately $25 \%$ (0.4-1.8 $\left.\mathrm{g} \mathrm{g} \mathrm{g}^{-1} \mathrm{DM}\right)$, whereas $\mathrm{NO}_{3}^{-}-\mathrm{N}$ contributed less than $3 \%$ (11-47 $\left.\mathrm{ng} \mathrm{g}^{-1} \mathrm{DM}\right)$. At both sites, the concentrations of water-extractable $\mathrm{NH}_{4}^{+}-\mathrm{N}$ and total amino acid $\mathrm{N}$ increased from July to August, whereas the concentration of DOC decreased (Table 2).

Among the amino acids, arginine made up approximately $46 \%$ of the total amino acid $\mathrm{N}$ at the shrub tundra and 2 and $68 \%$ of total amino acid $\mathrm{N}$ at the heath tundra in July and August, respectively. Alanine, glycine, valine, 
Table 2 Biotic and abiotic soil $\mathrm{C}$ and $\mathrm{N}$ pools at a heath and a shrub tundra near Abisko, subarctic Sweden

\begin{tabular}{|c|c|c|c|c|c|}
\hline \multirow[t]{2}{*}{ Soil pool ( $\mu \mathrm{g} \mathrm{g}^{-1}$ dry mass) } & \multicolumn{2}{|l|}{ Heath tundra } & \multicolumn{2}{|l|}{ Shrub tundra } & \multirow[t]{2}{*}{ Main factor effects ${ }^{a}$} \\
\hline & July & August & July & August & \\
\hline Fungal biomass $C^{b}$ & $6,976 \pm 720$ & $9,845 \pm 1,684$ & $4,644 \pm 455$ & $4,309 \pm 287$ & Site ${ }^{* *}$, Site $\times$ date $\dagger$ \\
\hline Microbial biomass $\mathrm{C}_{\mathrm{K}_{2} \mathrm{SO}_{4}}{ }^{\mathrm{c}}$ & $7,210 \pm 545$ & $8,716 \pm 589$ & $11,340 \pm 599$ & $13,844 \pm 1,060$ & Site ${ }^{* * *}$, date d $^{* *}$ \\
\hline Microbial biomass $\mathrm{N}_{\mathrm{K}_{2} \mathrm{SO}_{4}}$ & $888 \pm 110$ & $973 \pm 124$ & $1,378 \pm 74$ & $1,145 \pm 71$ & Site** \\
\hline $\mathrm{DOC}_{\mathrm{K}_{2} \mathrm{SO}_{4}}$ & $597 \pm 64$ & $533 \pm 42$ & $860 \pm 54$ & $668 \pm 55$ & Site $* * *$, date $* *$ \\
\hline $\mathrm{DTN}_{\mathrm{K}_{2} \mathrm{SO}_{4}}$ & $54.7 \pm 7.9$ & $43.0 \pm 8.6$ & $98.3 \pm 8.3$ & $90.8 \pm 5.6$ & Site $* * *$ \\
\hline $\mathrm{NH}_{4}^{+}-\mathrm{N}_{\mathrm{K}_{2} \mathrm{SO}_{4}}$ & $1.95 \pm 0.49$ & $2.91 \pm 0.54$ & $8.86 \pm 3.25$ & $5.69 \pm 0.99$ & Site* \\
\hline $\mathrm{NH}_{4}^{+}-\mathrm{N}_{\mathrm{H}_{2} \mathrm{O}}$ & $1.41 \pm 0.28$ & $3.21 \pm 0.41$ & $3.04 \pm 0.27$ & $4.47 \pm 0.47$ & Site $* * *$, date $* * *$ \\
\hline $\mathrm{NO}_{3}^{-}-\mathrm{N}_{\mathrm{H}_{2} \mathrm{O}}$ & $0.047 \pm 0.012$ & $0.032 \pm 0.015$ & $0.011 \pm 0.006$ & $0.029 \pm 0.010$ & Site $\dagger$ \\
\hline Glycine- $\mathrm{N}_{\mathrm{H}_{2} \mathrm{O}}$ & $0.056 \pm 0.030$ & $0.051 \pm 0.023$ & $0.094 \pm 0.050$ & $0.121 \pm 0.043$ & \\
\hline Total amino acid $\mathrm{N}_{\mathrm{H}_{2} \mathrm{O}}$ & $0.363 \pm 0.105$ & $1.776 \pm 0.608$ & $1.188 \pm 0.237$ & $1.818 \pm 0.300$ & Date* \\
\hline Total available $\mathrm{N}_{\mathrm{H}_{2} \mathrm{O}}{ }^{\mathrm{d}}$ & $1.82 \pm 0.35$ & $5.02 \pm 0.87$ & $4.24 \pm 0.37$ & $6.32 \pm 0.74$ & Site ${ }^{* *}$, date d $^{* * *}$ \\
\hline
\end{tabular}

Values are given as the means \pm standard error

a Significant main factor effects (site and date) and interactions in ANOVAs are indicated as $* P<0.05$, ** $P<0.01, * * * P<0.001, \dagger P<0.10$

b Estimated from the ergosterol concentration in bulk soil assuming $3.5 \mu \mathrm{g}$ ergosterol and $430 \mu \mathrm{g} \mathrm{C} \mathrm{mg}^{-1}$ fungal biomass (Salmanowicz and Nylund 1988; Montgomery et al. 2000)

${ }^{c}$ The extractant was either $0.1 \mathrm{M} \mathrm{K}_{2} \mathrm{SO}_{4}$ or water as indicated in subscript

d Total available $\mathrm{N}$ : the sum of $\mathrm{NH}_{4}^{+}-\mathrm{N}, \mathrm{NO}_{3}^{-}-\mathrm{N}$ and amino acid $\mathrm{N}$

glutamic acid and serine constituted most of the remaining amino acid pool at both sites (ESM S3).

Partitioning of ${ }^{15} \mathrm{~N}$ label into major ecosystem pools

Immediately after the addition of tracers, the pools of glycine-, $\mathrm{NH}_{4}^{+}$and $\mathrm{NO}_{3}^{-}-{ }^{15} \mathrm{~N}$ made up, on average, 99.7 , 92.3 and $99.7 \%$ of the total glycine-, $\mathrm{NH}_{4}^{+}$and $\mathrm{NO}_{3}^{-}-\mathrm{N}$ pools at the heath tundra and $99.6,89.6$ and $99.9 \%$ at the shrub tundra. These ${ }^{15} \mathrm{~N}$ amounts corresponded to 16 and $15 \%$ of the DTN pools at the heath and shrub tundra, respectively, including the added, unlabelled N. After 2 days, the $\mathrm{DT}^{15} \mathrm{~N}$ constituted less than $0.1 \%$ of the DTN pool at both sites.

Ecosystem ${ }^{15} \mathrm{~N}$ recovery (i.e. plant + soil) tended to decrease with time in the soil-injected plots, probably because of label movement out of the harvested area (ESM, $\mathrm{S} 2)$. In contrast, ecosystem ${ }^{15} \mathrm{~N}$ recovery increased with time in the bag-injected plots because of the movement of the label out of the bags into the bulk soil. Ecosystem ${ }^{15} \mathrm{~N}$ recovery was also significantly affected by the ${ }^{15} \mathrm{~N}$ form added both in soil- and bag-injected plots; this is probably related to differences in the mobility of the three $\mathrm{N}$ forms combined with methodological uncertainties in the ${ }^{15} \mathrm{~N}$ recovery estimate (see discussion in Grogan et al. 2004).

The proportional partitioning of the ${ }^{15} \mathrm{~N}$ recovered in the soil-plant system, however, showed a similar pattern for soil- and bag-labelled plots (Fig. 1). Two days after labelling, the proportion of ${ }^{15} \mathrm{~N}$ in plants was $5-10 \%$ of the recovered ${ }^{15} \mathrm{~N}$ at the heath tundra and $8-16 \%$ at the shrub tundra; after 26 days, the corresponding proportions were 10-20 and $15-25 \%$ (Fig. 1). Two days after labelling, the ${ }^{15} \mathrm{~N}$ recovery in the microbial biomass at both sites did not differ from ${ }^{15} \mathrm{~N}$ recovery measured in the bulk soil, implying that nearly all ${ }^{15} \mathrm{~N}$ in the bulk soil was immobilized by microbes (Fig. 1). Over the following 24 days, the ${ }^{15} \mathrm{~N}$ recovery in the microbial biomass decreased to about half (heath) and two-thirds (shrub) of the bulk soil ${ }^{15} \mathrm{~N}$. At both harvests, very small proportions $-<0.5 \%$ at the heath tundra and $0.5-1 \%$ at the shrub tundra- of the recovered ${ }^{15} \mathrm{~N}$ were found in the DTN pool (Fig. 1).

Plants acquired a larger proportion of $\mathrm{NO}_{3}^{-15} \mathrm{~N}$ than glycine- and $\mathrm{NH}_{4}^{+}-{ }^{15} \mathrm{~N}$ when added to the soil. With ${ }^{15} \mathrm{~N}$ label added to the bags, plants showed a similar pattern at the heath, but they acquired more $\mathrm{NH}_{4}^{+}{ }^{15} \mathrm{~N}$ than glycine- ${ }^{15} \mathrm{~N}$ at the shrub tundra (Fig. 1). In contrast, there were no significant differences in the ${ }^{15} \mathrm{~N}$ recovered from the three ${ }^{15} \mathrm{~N}$ sources in terms of microbial biomass $\mathrm{N}$ or DTN pools, with the exception of a marginally significantly higher recovery of glycine- than of $\mathrm{NO}_{3}^{-}-{ }^{15} \mathrm{~N}$ in microbes after 26 days at the heath tundra (Fig. 1).

ECM mycelial vs. B. nana $\mathrm{N}$ uptake patterns

Natural ${ }^{13} \mathrm{C}$ abundance $\left(\delta^{13} \mathrm{C}\right)$ of mycelia extracted from the unlabelled ingrowth bags ranged between -26.9 and 

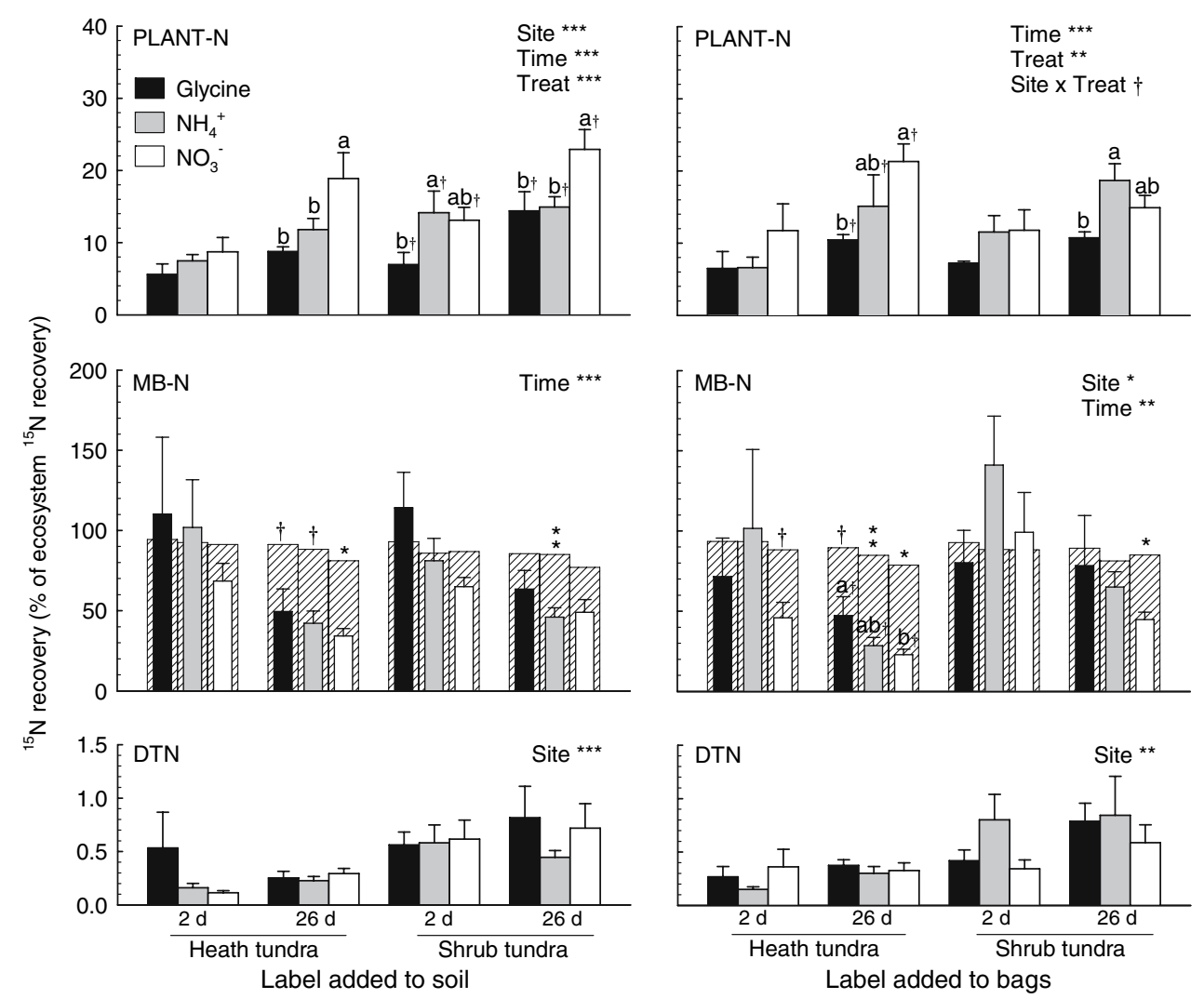

Fig. 1 Proportional recovery of ${ }^{15} \mathrm{~N}$ from ${ }^{15} \mathrm{~N}$-labelled glycine (black bars), $\mathrm{NH}_{4}^{+}$(grey bars) or $\mathrm{NO}_{3}^{-}$(white bars) in pools of plant $\mathrm{N}$, soil microbial biomass $\mathrm{N}(M B-N)$ and dissolved total $\mathrm{N}(D T N) 2$ and 26 days after injection into soil or fungal ingrowth bags at a heath tundra and a shrub tundra in subarctic Swedish Lapland. The three N forms were added as equimolar mixtures with one $\mathrm{N}$ form labelled at a time. Significant main factor effects (site, incubation time and treatment) and interactions in ANOVAs are indicated as

$-26.6 \%$ at the heath tundra and between -27.7 and $-27.0 \%$ at the shrub tundra. These values are well within the range of the ${ }^{13} \mathrm{C}$ abundance of ECM fruitbodies in a nearby heath (Clemmensen et al. 2006), strongly indicating an ECM origin of the bulk of the mycelia (Wallander et al. 2001). The mycelia showed strong $\mathrm{N}$-form preferences at both sites (Fig. 2). Mycelial net uptake of $\mathrm{NH}_{4}^{+}{ }^{15} \mathrm{~N}$ after 26 days was 10.0 - and 6.3fold higher than the net uptake of $\mathrm{NO}_{3}^{-}-{ }^{15} \mathrm{~N}$ at the heath tundra and shrub tundra, respectively, and the net ${ }^{15} \mathrm{~N}$ uptake from the glycine source was 5.1-fold higher than the $\mathrm{NO}_{3}^{-}-{ }^{15} \mathrm{~N}$ uptake at the heath but similar to the $\mathrm{NO}_{3}^{-}-{ }^{15} \mathrm{~N}$ uptake at the shrub tundra. The mycelial biomass in the bags was higher at the shrub tundra than at the heath tundra and increased strongly during the incubation period at both sites (Fig. 2). The mycelial biomass did not differ significantly among treatments, but mycelial growth was stimulated by the $\mathrm{N}$ additions, as shown by the higher mean biomass in treated bags in August $(182 \pm 25$ at the heath tundra and
$* * * P<0.001, * * P<0.01, * P<0.05, \dagger P<0.10$. Different letters above the bars indicate differences among treatments within a site and time period $(P<0.05)$; marginally significant differences are followed by $\dagger(P<0.10)$. Recovery in bulk soil (hatched bars) is shown as a reference, asterisks indicate significant differences between microbial and bulk soil ${ }^{15} \mathrm{~N}$ recovery $(t$ tests). Bars represent means $+\mathrm{SE}, n=6$

$255 \pm 42 \mathrm{mg} \mathrm{m}^{-2}$ at the shrub tundra) than in untreated control bags $(77 \pm 24$ at the heath tundra and $87 \pm 26 \mathrm{mg} \mathrm{m}^{-2}$ at the shrub tundra; $P<0.05, t$ tests). Net ${ }^{15} \mathrm{~N}$ accumulation in the mycelia represented less than $0.5 \%$ of the total ${ }^{15} \mathrm{~N}$ amount added to the bags. The mycelial C:N ratios of approximately 20 were largely unaffected by the additions of $\mathrm{N}$, but they were marginally higher $(P=0.09)$ at the heath tundra than at the shrub tundra (Fig. 2).

Betula nana, the dominant ECM plant species at both sites, also showed strong $\mathrm{N}$ uptake patterns. When the label was added directly to the soil, ${ }^{15} \mathrm{NH}_{4}^{+}$addition lead to a higher ${ }^{15} \mathrm{~N}$ concentration in the fine roots than the other two ${ }^{15} \mathrm{~N}$ treatments (Fig. 3). When the label was added to the ingrowth bags, the ${ }^{15} \mathrm{~N}$ concentrations in the fine roots were generally higher at the shrub tundra than at the heath tundra, and 26 days after labelling the shrub tundra ${ }^{15} \mathrm{~N}$ concentrations were 4.5- and 5.3-fold higher in the ${ }^{15} \mathrm{~N}$ glycine and ${ }^{15} \mathrm{NH}_{4}^{+}$treatments, respectively, than in the ${ }^{15} \mathrm{NO}_{3}^{-}$treatment (Fig. 3). The ${ }^{15} \mathrm{~N}$ concentrations were 

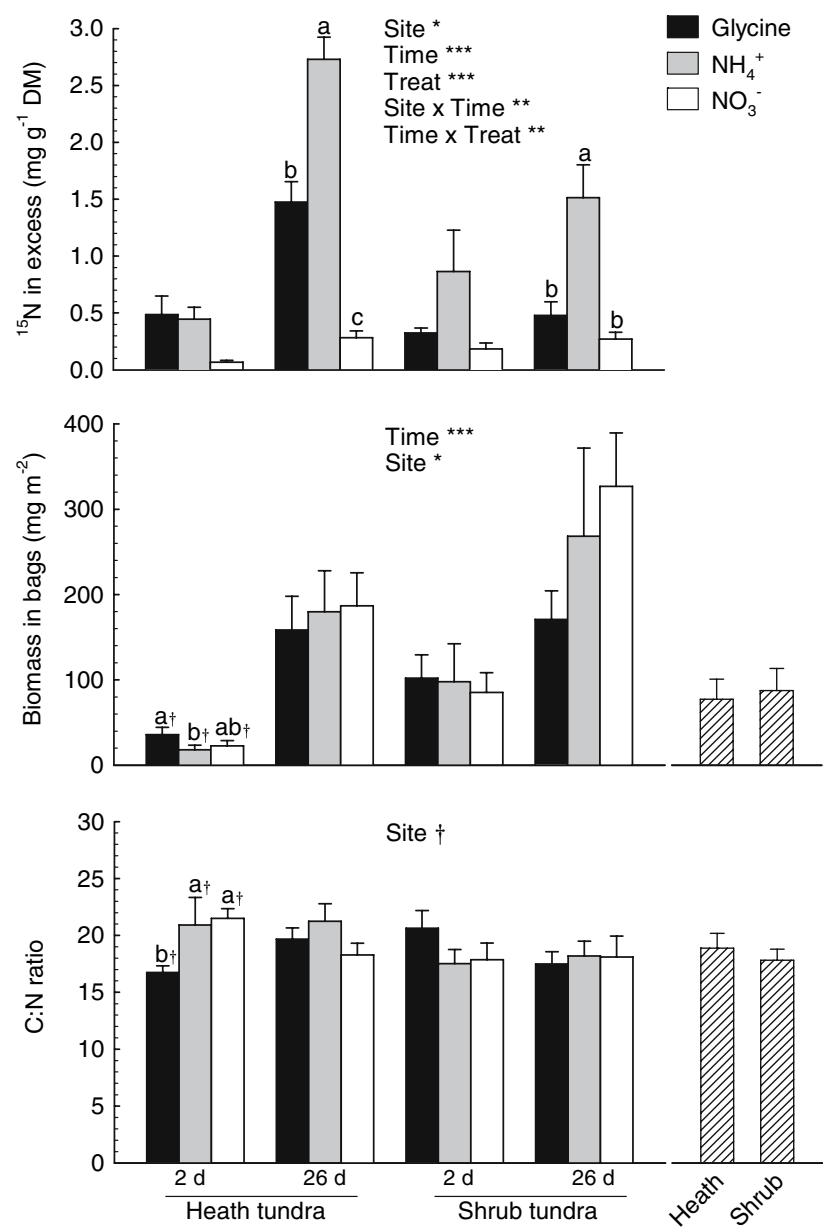

Fig. 2 Mycelial ${ }^{15} \mathrm{~N}$ enrichment, biomass and C:N ratio of ectomycorrhizal mycelia extracted from ingrowth bags 2 and 26 days after labelling with ${ }^{15} \mathrm{~N}$-enriched glycine (black bars), $\mathrm{NH}_{4}^{+}$(gray bars) or $\mathrm{NO}_{3}^{-}$(white bars). The three $\mathrm{N}$ forms were added as equimolar mixtures with one $\mathrm{N}$ form labelled at a time. Significant main factor effects (site, incubation time and treatment) and interactions are indicated as $* * * P<0.001, * * P<0.01, * P<0.05, \dagger P<0.10$. Different letters above the bars indicate differences among treatments within a site and time period $(P<0.05)$; marginally significant differences are followed by $\dagger(P<0.10)$. Mycelial biomass and $\mathrm{C}: \mathrm{N}$ ratio in untreated controls (hatched bars) are shown as reference. Bars represent means $+\mathrm{SE}, n=6$

generally two orders of magnitude lower in the fine roots than in the mycelia.

The net ${ }^{15} \mathrm{~N}$ accumulation pattern in whole plants generally mirrored fine-root ${ }^{15} \mathrm{~N}$ uptake, although net uptake was significantly higher at the shrub tundra than at the heath mainly as a result of the larger biomass of $B$. nana (Fig. 3). Net ${ }^{15} \mathrm{~N}$ uptake increased with time at the shrub tundra but not at the heath, as seen by the significant interaction between site and time in the models. Overall, in the soil-labelled plots, ${ }^{15} \mathrm{~N}$ recovery from the ${ }^{15} \mathrm{NH}_{4}^{+}$source was higher than that from the ${ }^{15} \mathrm{~N}$-glycine source, whereas the net uptake of ${ }^{15} \mathrm{NO}_{3}^{-}$did not differ significantly from the uptake of the other $\mathrm{N}$ sources.
Uptake of intact glycine

Uptake of glycine-derived ${ }^{13} \mathrm{C}$ and ${ }^{15} \mathrm{~N}$ was correlated in both soil microbial biomass and in ECM mycelia, although not significantly so in mycelia at the heath, presumably because of low replication. The correlation suggests that glycine was absorbed, at least partly, in intact form (Fig. 4). After 2 days, the regression slopes were lower than (microbial biomass) or similar to (mycelia) the ratio of two in the added $\mathrm{U}-{ }^{13} \mathrm{C}-{ }^{15} \mathrm{~N}$-glycine, whereas after 26 days, all regression slopes were significantly lower than 2. The fraction of glycine-derived ${ }^{15} \mathrm{~N}$ taken up as intact amino acid estimated after 2 days was 55 and $42 \%$ of the total ${ }^{15} \mathrm{~N}$ uptake from the labelled glycine source for the microbial biomass and 73 and $67 \%$ for mycelia at the heath tundra and shrub tundra sites, respectively. In ECM mycelia, the regression slopes declined strongly with time at both sites $(P<0.05)$, whereas in the microbial biomass, the slope only declined significantly at the shrub tundra. Similarly, the ${ }^{13} \mathrm{C}-{ }^{15} \mathrm{~N}$-ratios decreased strongly with time for mycelia but were unchanged with time for the microbial biomass (ESM, S4). We found no significant ${ }^{13} \mathrm{C}-{ }^{15} \mathrm{~N}-$ correlations in plant fractions because of the large pool dilution of ${ }^{13} \mathrm{C}$ in plant tissues. However, the plant ${ }^{13} \mathrm{C}-{ }^{15} \mathrm{~N}$-ratios were significantly different from zero 2 days after injections at both sites (mean - 95\% confidence limit of the mean exceeded 0) (ESM, S4), indicating that plants took up part of the added ${ }^{13} \mathrm{C}$.

\section{Discussion}

Microbial control on growing season $\mathrm{N}$ cycling

Our tracer studies at two highly contrasting tundra sites revealed that soil microbial biomass constitutes a major short-term sink for exogenously added $\mathrm{N}$, thereby confirming the few earlier field studies in arctic tussock or forest tundras (Schimel and Chapin 1996; Grogan and Jonasson 2003; Nordin et al. 2004). Both at the heath and shrub tundra, virtually all of the ${ }^{15} \mathrm{~N}$ recovered in the bulk soil was immobilized by microbes as early as 2 days following the addition of the ${ }^{15} \mathrm{~N}$ pulse, although microbial biomass contained only $6 \%$ (heath) and $11 \%$ (shrub tundra) of the native soil $\mathrm{N}$ pools. The strong decline in the proportion of label incorporated into soil microbes over the subsequent 24 days together with minor changes in ${ }^{15} \mathrm{~N}$ recovery in the bulk soil and the dissolved ${ }^{15} \mathrm{~N}$ pool indicates fixation of the label into stable soil organic $\mathrm{N}$ pools (Fig. 1). A similar pattern of label movement from microbes to bulk soil has been observed in taiga forest soils (McFarland et al. 2002) and in subarctic heath soils (Grogan and Jonasson 2003; Grogan et al. 2004). In the 
Fig. 3 Betula nana fine root

${ }^{15} \mathrm{~N}$ recovery 2 and 26 days

after injecting ${ }^{15} \mathrm{~N}$-enriched glycine (black bars), $\mathrm{NH}_{4}^{+}$(gray bars) or $\mathrm{NO}_{3}^{-}$(white bars) into soil or ingrowth bags at heath tundra and shrub tundra in subarctic Swedish Lapland. The three $\mathrm{N}$ forms were added as equimolar mixtures with one $\mathrm{N}$ form labelled at a time.

Significant main factor effects treatment) and interactions are indicated as $* * * P<0.001$, $* * P<0.01, * P<0.05, \dagger$ $P<0.10$. Different letters above the bars indicate differences among treatments within a site and time period $(P<0.05)$. Marginally significant differences are followed by $\dagger(P<0.10)$. Bars represent means $+\mathrm{SE}, n=6$
${ }^{15} \mathrm{~N}$ enrichment and total plant (site, incubation time and
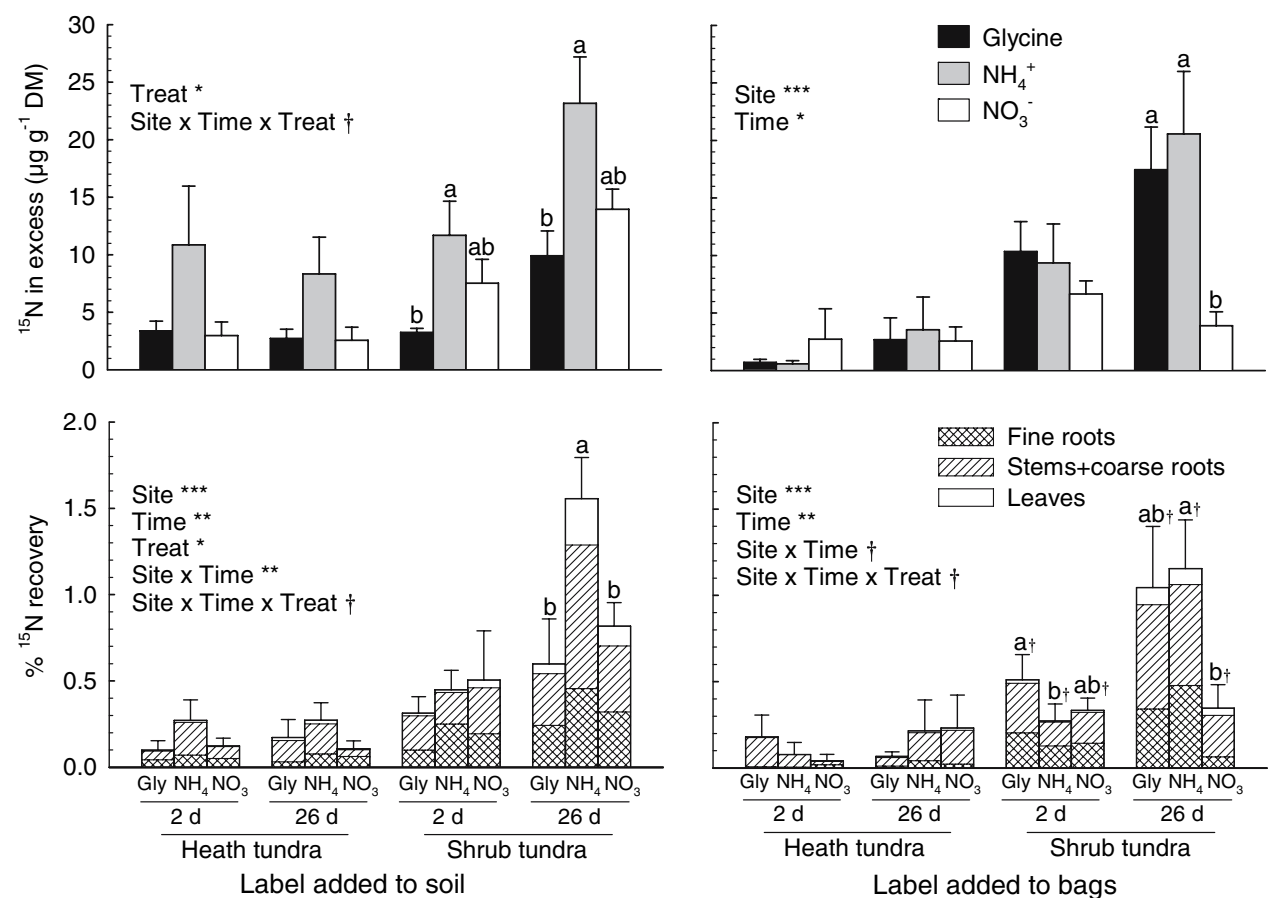

latter study, gaseous and leachate $\mathrm{N}$ losses were furthermore shown to be minimal (Grogan et al. 2004). This pattern suggests that microbial biomass turnover paired with the exudation of ${ }^{15} \mathrm{~N}$-containing substances, such as extracellular enzymes, is the most important mechanism of $\mathrm{N}$ retention and turnover in the ecosystems studied. In contrast, Kaye et al. (2003) suggested that stable ${ }^{15} \mathrm{~N}$ retention in floodplain soils mainly resulted from chemical reactions between added $\mathrm{NH}_{4}^{+}$and organic matter.

Alternatively, we cannot exclude that the microbial ${ }^{15} \mathrm{~N}$ decline could partly have resulted from the methodological procedures applied, as freshly assimilated label may be more chloroform labile than the total microbial $\mathrm{N}$ pool, which was used for calibrating the extraction factors. If this was the case, it could have led to an overestimation of ${ }^{15} \mathrm{~N}$ recovery in the microbial biomass 2 days after the label addition (Schimel and Chapin 1996). We believe, however, that this explains only a minor part of the change because the decrease in microbial ${ }^{15} \mathrm{~N}$ observed by Grogan and Jonasson (2003) occurred in the growing season in the year following ${ }^{15} \mathrm{~N}$ additions and could not have been affected by changes in chloroform lability. Furthermore, the ${ }^{15} \mathrm{~N}$ recovery in microbes after the longer term incubations may be underestimated because the proportion of label incorporated into recalcitrant cell-wall constituents increase with time after label addition, when uptake of the native soil $\mathrm{N}$ pools becomes more important.

The initial ${ }^{15} \mathrm{~N}$ net uptake by plants was an order of magnitude lower than the uptake by microorganisms, which is similar to the plant-microbial ${ }^{15} \mathrm{~N}$ partitioning found in previous short-term tracer studies in arctic tundra
(Schimel and Chapin 1996; Grogan and Jonasson 2003; Nordin et al. 2004). Pulse labelling studies like ours may even overestimate the natural uptake rate by plants, as plants are more competitive for small $\mathrm{N}$ compounds at high soil solution concentrations because the uptake capacity of the microbial communities may become saturated (Vinolas et al. 2001; Jones et al. 2005b). Regardless of this uncertainty, our study demonstrates that subarctic plants can potentially take advantage of discrete incidents of increased fluxes of all three forms of available $\mathrm{N}$.

After the initial, rapid $\mathrm{N}$ uptake, the plants presumably sequestered additional ${ }^{15} \mathrm{~N}$ from the fraction initially immobilized by microbes. Hence, while microbes were efficient competitors for $\mathrm{N}$ in the short term, plants gained access to this $\mathrm{N}$ over longer term perspectives because of their longer tissue longevity and slower turnover (Hodge et al. 2000). Also, it is highly possible that some of the microbially immobilized ${ }^{15} \mathrm{~N}$ was taken up by mycorrhizal fungi and transferred directly to symbiotic plants with some time lapse, as ectomycorrhizal fungi are able to retain $\mathrm{N}$ even in situations in which their plant symbiont remains in a state of $\mathrm{N}$ limitation (Aber et al. 1998; Simard and Durall 2004). Unfortunately, there are no methods to distinguish label incorporation into functionally different microbial populations, such as the saprotrophic versus the mycorrhizal fungal pools in the soil. Ectomycorrhizal fungi at both of our tundra sites, however, showed great potential for proliferation in nutritional hot spots, as shown by the increased mycelial production in ingrowth bags following the $\mathrm{N}$ additions (Fig. 2). This suggests that ECM fungi captured the added $\mathrm{N}$ efficiently and transferred some of it 

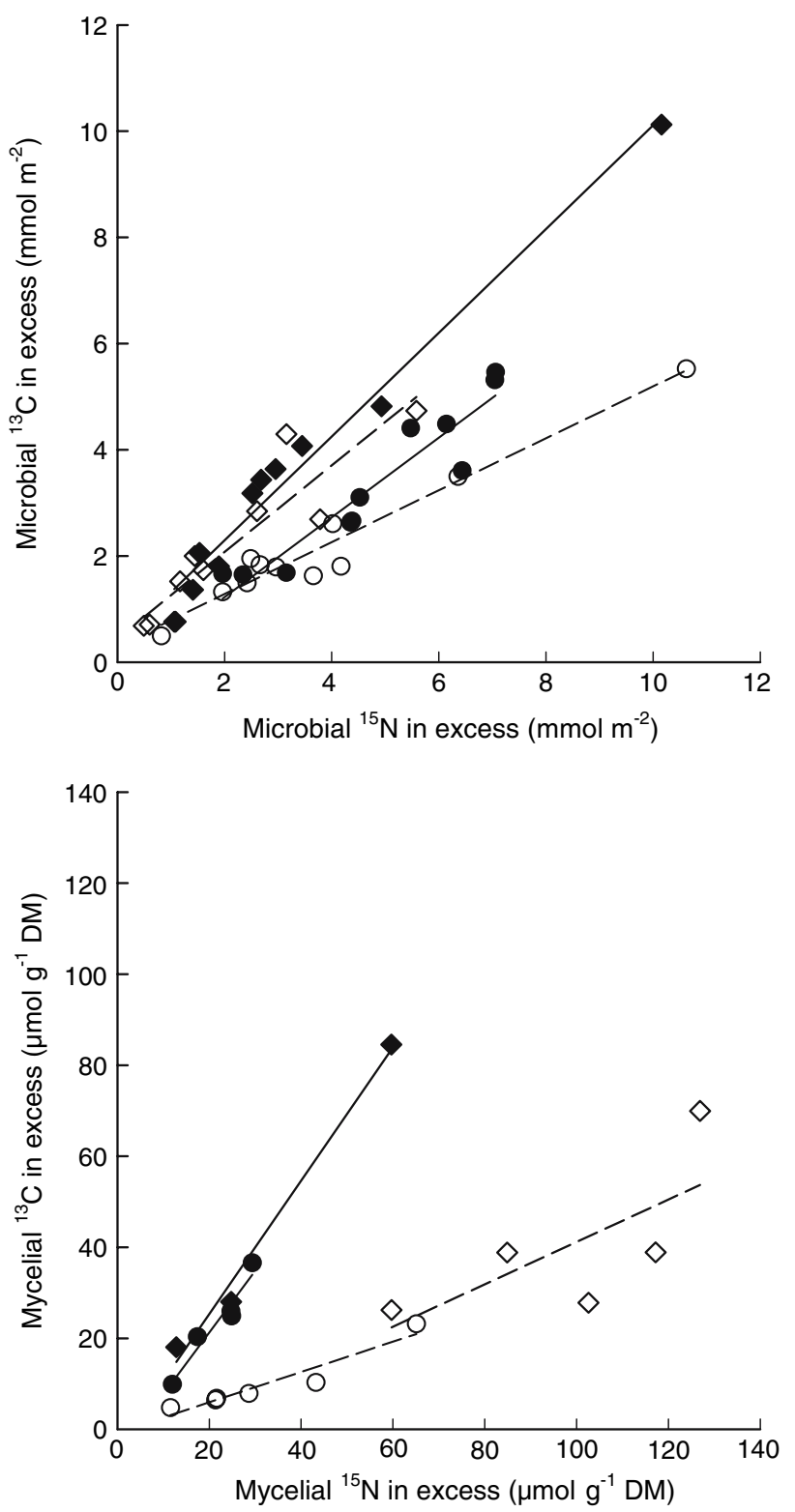

Fig. 4 The relationship between ${ }^{15} \mathrm{~N}$ and ${ }^{13} \mathrm{C}$ enrichment in soil microbes and in ectomycorrhizal mycelia at heath tundra (squares) and shrub tundra (circles) 2 days (filled symbols) and 26 days (open symbols) after labelling with $\mathrm{U}-{ }^{13} \mathrm{C}-{ }^{15} \mathrm{~N}$-glycine. Each symbol represents one sample, except at heath after 2 days where mycelial samples were pooled in groups of two prior to analyses. Lines indicate linear regressions; for microbial biomass at heath tundra (2 days, $y=0.98 x+0.34, r^{2}=0.98 ; 26$ days, $\left.y=0.82 x+0.44, r^{2}=0.84\right)$ and at shrub tundra ( 2 days, $y=0.75 x-0.28, r^{2}=0.89 ; 26$ days, $\left.y=0.49 x+0.30, r^{2}=0.95\right), P<0.001$ for all; for mycelia at heath tundra $\left(2\right.$ days, $y=1.46 x-3.96, r^{2}=0.99, P<0.10 ; 26 \mathrm{~d}$, $y=0.47 x-5.38, r^{2}=0.50$, n.s.) and at shrub tundra (2 days, $y=1.35 x-5.88, r^{2}=0.93, P<0.01 ; 26$ days, $y=0.33 x-0.77$, $\left.r^{2}=0.91, P<0.01\right), P$ is as indicated

to the plants and other parts of the mycelial systems (PerezMoreno and Read 2000). Thus, it appears that soil microbes govern $\mathrm{N}$ transformations and provide plants with
$\mathrm{N}$ during the arctic growing season, while plants sustain microbial activity and biomass through $\mathrm{C}$-allocation below ground and, on longer terms, through their litter production.

$\mathrm{N}$-form uptake patterns in plants and microbes

In contrast to some earlier studies (Kielland 1994; Nordin et al. 2001, 2004), we found no marked difference in $\mathrm{N}$ form uptake patterns in plants that could be related to $\mathrm{N}$ form prevalence at the two sites, although we cannot exclude that single plant species or functional groups may have shown distinct patterns that were masked by our pooling of plant species. This could be caused by the fact that although the total available $\mathrm{N}$ pool was larger at the shrub tundra than at the heath tundra, the proportional contributions by the three $\mathrm{N}$ forms were similar at the two sites; $\mathrm{NH}_{4}^{+}-\mathrm{N}$ made up about two-thirds of the available $\mathrm{N}$ pool, and free amino acids made up the rest, with a minor contribution by $\mathrm{NO}_{3}^{-}-\mathrm{N}$. Furthermore, the high depletion rates of all added ${ }^{15} \mathrm{~N}$ forms suggest that the sizes of available soil $\mathrm{N}$ pools may be poorly related to $\mathrm{N}$ availability in these ecosystems. The sizes of the available $\mathrm{N}$ pool may depend more on the production rates of mineralized $\mathrm{N}$ together with the abundance and uptake kinetics of the biota present. The endogenous soil pools of all three $\mathrm{N}$ forms used in this study probably have very fast turnover times (hours), as also indicated by studies in other organogenic soils (Stark and Hart 1997; Jones and Kielland 2002).

In both of the tundra types studied, plants generally competed better for added $\mathrm{NO}_{3}^{-}$than for glycine; to some extent, this was also true for $\mathrm{NH}_{4}^{+}$(Fig. 1). This result agrees with the only earlier field study of $\mathrm{N}$ uptake using $\mathrm{N}$-form mixtures in arctic ecosystems that we are aware of, which showed a larger uptake of inorganic $\mathrm{N}$ (mostly $\mathrm{NO}_{3}^{-}$) than of amino acid $\mathrm{N}$ by most plant species (Nordin et al. 2004). McKane et al. (2002) also found a high acquisition of $\mathrm{NO}_{3}^{-}$in comparison to other $\mathrm{N}$ forms in some tundra plants, although the $\mathrm{N}$ forms were not added together. The relatively higher mobility of $\mathrm{NO}_{3}^{-}$in the soil, as compared to the other $\mathrm{N}$ forms, may have contributed to high plant access to $\mathrm{NO}_{3}^{-}$; the diffusion rate of $\mathrm{NO}_{3}^{-}$is fivefold higher than that of $\mathrm{NH}_{4}^{+}$and amino acids (Jones et al. 2005a).

Our in situ study clearly demonstrated that soil microbial biomass and ECM mycelia took up glycine-at least partly-in intact form. After an initial loss of glycinederived ${ }^{13} \mathrm{C}$, the amount of microbial ${ }^{13} \mathrm{C}$ decreased in proportion to or only slightly faster than microbial ${ }^{15} \mathrm{~N}$, as shown by similar regression slopes and ${ }^{13} \mathrm{C}:{ }^{15} \mathrm{~N}$ ratios at the two sampling dates. This relationship was probably due to the decarboxylation of the $\mathrm{U}-{ }^{13} \mathrm{C}-{ }^{15} \mathrm{~N}$-glycine within 
the first 2 days following its addition and the products being directly allocated to structural compounds that turned over with the microbial biomass (Vinolas et al. 2001; Persson et al. 2003). In contrast, plants and ECM mycelia lost a larger proportion of assimilated glycine-derived ${ }^{13} \mathrm{C}$ than ${ }^{15} \mathrm{~N}$; in plants, this probably occurred because the glycine was fully metabolized in the mycorrhizal roots before the $\mathrm{N}$ was transferred to the rest of the plant (Taylor et al. 2004). The generally lower ${ }^{13} \mathrm{C}:{ }^{15} \mathrm{~N}$ ratios in all pools at the shrub tundra points to faster and more complete respiratory loss of glycine-derived ${ }^{13} \mathrm{C}$ (Näsholm et al. 1998), which is probably linked to water limitation at the heath (Illeris and Jonasson 1999).

$\mathrm{N}$ uptake patterns in ectomycorrhizal fungi and plants

The total amount of ${ }^{15} \mathrm{~N}$ accumulated in the ECM mycelia within the ingrowth bags after 26 days corresponded to less than $0.5 \%$ of the added ${ }^{15} \mathrm{~N}$ pools. Even when the movements of ${ }^{15} \mathrm{~N}$ from the bags to the surrounding soil and plants are taken into account, we assume that the amount of label in the bags was much larger than the uptake capacity of the mycelia present and, hence, that mycelial ${ }^{15} \mathrm{~N}$ concentrations represent fungal $\mathrm{N}$-form preferences rather than the outcome of competition with other soil organisms.

The ECM mycelia in the ingrowth bags strongly discriminated against $\mathrm{NO}_{3}^{-}$, which made up about $6 \%$ of the total $\mathrm{N}$ taken up from the $\mathrm{N}$ mixtures at the heath tundra and $12 \%$ at the shrub tundra, both in the short- and longterm incubations (Fig. 2). This is corroborated by pure culture studies where most ectomycorrhizal fungi grew better with $\mathrm{NH}_{4}^{+}$than with $\mathrm{NO}_{3}^{-}$(Finlay et al. 1992). Also, mycorrhizal roots had four- to 30-fold higher net uptake rates of glycine and $\mathrm{NH}_{4}^{+}$than of $\mathrm{NO}_{3}^{-}$at a range of concentrations (Wallander et al. 1997; Gessler et al. 2005). Thus, the low uptake preference for $\mathrm{NO}_{3}^{-}$compared to other $\mathrm{N}$ forms may be a common phenomenon in ECM fungi.

At the heath tundra, the ECM mycelia showed a stronger preference for glycine than for $\mathrm{NO}_{3}^{-}$, and glycine made up a larger proportion of total mycelial net $\mathrm{N}$ uptake here than at the shrub tundra (Fig. 2). Ectomycorrhizal fungal species vary widely in their uptake capacities for different $\mathrm{N}$ forms (Finlay et al. 1992; Leake and Read 1997). Hence, the difference in mycelial preference patterns between sites may be caused by different ECM fungi dominating the mycelial communities. At the heath tundra, with its tight $\mathrm{N}$ cycle, the ECM fungal community could be adapted to organic $\mathrm{N}$ acquisition, whereas at the shrub tundra, with its more open $\mathrm{N}$-cycle, $\mathrm{NH}_{4}^{+}$seems to be the main $\mathrm{N}$ form taken up by the ECM fungal community.
The $\mathrm{N}$-form preferences identified in ECM mycelia were not directly mirrored in the $\mathrm{N}$ uptake by $B$. nana, neither when the label was added directly to the soil nor when ECM mycelia in the ingrowth bags were provided label without competition from other biota. Unfortunately, the ${ }^{15} \mathrm{~N}$ enrichment level in B. nana was very low and variable at the heath when label was added to the ingrowth bags because of the low biomass of B. nana and small mass of ECM mycelia in the bags at the time of labelling. At the shrub tundra, however, when label was added to the mycelium, the uptake pattern in $B$. nana was different, with relatively lower uptake of $\mathrm{NO}_{3}^{-}$and a higher uptake from the glycine source than when label was added to the soil (Fig. 3). This result suggests that ECM mycelial communities dominated glycine uptake but played a minor role in plant $\mathrm{NO}_{3}^{-}$uptake. In laboratory studies, $B$. nana has been shown to depend upon ECM colonization for the utilization of glutamic acid or glycine as a sole $\mathrm{N}$ source for growth (Emmerton et al. 2001), which is in accordance with our results from the field. However, B. nana $\mathrm{N}$ uptake patterns were probably modified by competition for added ${ }^{15} \mathrm{~N}$ by saprotrophic microbes and other plant species, particularly when the label was added directly to the soil. Our results therefore demonstrate that the net $\mathrm{N}$ uptake by ectomycorrhizal plants is modulated by $\mathrm{N}$ uptake patterns of both fungal and plant symbionts and also affected by $\mathrm{N}$ sequestration by the free-living soil microbes.

\section{Conclusion}

We conclude that:

1. Soil microbial biomass constituted the major shortterm sink for $\mathrm{N}$ and played a major role in $\mathrm{N}$ turnover and retention in soils of contrasting arctic tundra ecosystems. However, plants slowly accumulated N initially immobilized by microbes.

2. Both plants and microbes took up all added $\mathrm{N}$ forms, with plants generally getting access to $\mathrm{N}$ types in the order: $\mathrm{NO}_{3}^{-}>\mathrm{NH}_{4}^{+}>$glycine.

3. ECM mycelia strongly discriminated against $\mathrm{NO}_{3}^{-}$and mycelial $\mathrm{N}$ uptake and transfer to $\mathrm{ECM}$ plants appeared to be dominated by glycine and $\mathrm{NH}_{4}^{+}$.

4. Our study clearly demonstrated that glycine was taken up in intact form by soil microbial biomass, by ectomycorrhizal mycelia (first field evidence) and, to some extent, by plants.

5. N uptake patterns in functionally and structurally different microbial communities and subsequent $\mathrm{N}$ transformations in soils should be further studied if we are to fully understand the $\mathrm{N}$ cycle of northern ecosystems. 
Acknowledgments The authors are grateful for the excellent facilities and logistic support provided by the Abisko Scientific Research Station (ANS). We thank Pia Nielsen, Jane Pedersen, Jette Brandt, Anders Tesgaard, Kasper Andersen and Peter Jannerup for help in the field, and Karin Larsen and Esben Nielsen for assistance with laboratory analyses. Inger Kappel Schmidt kindly provided advice on the ${ }^{15} \mathrm{~N}$ diffusion technique, and three anonymous reviewers provided valuable critique on the manuscript. This research was funded by ANS, The Faculty of Science, University of Copenhagen and The Danish Natural Science Research Council.

\section{References}

Aber J, McDowell W, Nadelhoffer K, Magill A, Berntson G, Kamakea M, McNulty S, Currie W, Rustad L, Fernandez I (1998) Nitrogen saturation in temperate forest ecosystemshypotheses revisited. Bioscience 48:921-934

Benjdia M, Rikirsch E, Muller T, Morel M, Corratge C, Zimmermann S, Chalot M, Frommer WB, Wipf D (2006) Peptide uptake in the ectomycorrhizal fungus Hebeloma cylindrosporum: characterization of two di- and tripeptide transporters (HcPTR2A and B). New Phytol 170:401-410

Brookes PC, Landman A, Pruden G, Jenkinson DS (1985) Chloroform fumigation and the release of soil nitrogen: a rapid direct extraction method to measure microbial biomass nitrogen in soil. Soil Biol Biochem 17:837-842

Chalot M, Brun A (1998) Physiology of organic nitrogen acquisition by ectomycorrhizal fungi and ectomycorrhizas. FEMS Microbiol Rev 22:21-44

Clemmensen KE, Michelsen A (2006) Integrated long-term responses of an arctic-alpine willow and associated ectomycorrhizal fungi to an altered environment. Can J Bot 84:831-843

Clemmensen KE, Michelsen A, Jonasson S, Shaver GR (2006) Increased ectomycorrhizal fungal abundance after long-term fertilization and warming of two arctic tundra ecosystems. New Phytol 171:391-404

Emmerton KS, Callaghan TV, Jones HE, Leake JR, Michelsen A, Read DJ (2001) Assimilation and isotopic fractionation of nitrogen by mycorrhizal and nonmycorrhizal subarctic plants. New Phytol 151:513-524

Finlay RD, Frostegård ̊, Sonnerfeldt A-M (1992) Utilization of organic and inorganic nitrogen sources by ectomycorrhizal fungi in pure culture and in symbiosis with Pinus contorta Dougl. ex Loud. New Phytol 120:105-115

Finzi AC, Berthrong ST (2005) The uptake of amino acids by microbes and trees in three cold-temperate forests. Ecology 86:3345-3353

Fisk MC, Schmidt SK (1996) Microbial responses to nitrogen additions in alpine tundra soils. Soil Biol Biochem 28:751-755

Gessler A, Jung K, Gasche R, Papen H, Heidenfelder A, Borner E, Metzler B, Augustin S, Hildebrand E, Rennenberg H (2005) Climate and forest management influence nitrogen balance of European beech forests: microbial $\mathrm{N}$ transformations and inorganic $\mathrm{N}$ net uptake capacity of mycorrhizal roots. Eur $\mathrm{J}$ For Res 124:95-111

Gooday GW (1990) The ecology of chitin degradation. Adv Microbial Ecol 11:387-430

Grogan P, Jonasson S (2003) Controls on annual nitrogen cycling in the understory of a subarctic birch forest. Ecology 84:202-218

Grogan P, Michelsen A, Ambus P, Jonasson S (2004) Freeze-thaw regime effects on carbon and nitrogen dynamics in sub-arctic heath tundra mesocosms. Soil Biol Biochem 36:641-654
Hodge A, Robinson D, Fitter A (2000) Are microorganisms more effective than plants at competing for nitrogen? Trends Plant Sci 5:304-308

Illeris L, Jonasson S (1999) Soil and plant $\mathrm{CO}_{2}$ emission in response to variations in soil moisture and temperature and to amendment with nitrogen, phosphorus, and carbon in northern Scandinavia. Arct Antarct Alp Res 31:264-271

Jonasson S, Michelsen A, Schmidt IK, Nielsen EV (1999) Responses in microbes and plants to changed temperature, nutrient, and light regimes in the arctic. Ecology 80:1828-1843

Jones DL, Kielland K (2002) Soil amino acid turnover dominates the nitrogen flux in permafrost-dominated taiga forest soils. Soil Biol Biochem 34:209-219

Jones DL, Healey JR, Willett VB, Farrar JF, Hodge A (2005a) Dissolved organic nitrogen uptake by plants-an important $\mathrm{N}$ uptake pathway? Soil Biol Biochem 37:413-423

Jones DL, Shannon D, Junvee-Fortune T, Farrarc JF (2005b) Plant capture of free amino acids is maximized under high soil amino acid concentrations. Soil Biol Biochem 37:179-181

Kaye JP, Hart SC (1997) Competition for nitrogen between plants and soil microorganisms. Trend Ecol Evol 12:139-143

Kaye JP, Binkley D, Rhoades C (2003) Stable soil nitrogen accumulation and flexible organic matter stoichiometry during primary floodplain succession. Biogeochemistry 63:1-22

Kielland K (1994) Amino acid absorption by arctic plants: implications for plant nutrition and nitrogen cycling. Ecology 75:23732383

Leake JR, Donnelly DP, Boddy L (2002) Interactions between ectomycorrhizal and saprotrophic fungi. In: van der Heijden MGA, Sanders IR (eds) Mycorrhizal ecology, vol 1. Springer, Berlin, pp 345-372

Leake JR, Read DJ (1997) Mycorrhizal fungi in terrestrial habitats. In: Wicklow DT, Söderström B (eds) Environmental and microbial relationships, vol 4. Springer, Berlin, pp 281-301

Lindahl BO, Taylor AFS, Finlay RD (2002) Defining nutritional constraints on carbon cycling in boreal forests-towards a less 'phytocentric' perspective. Plant Soil 242:123-135

Lipson D, Näsholm T (2001) The unexpected versatility of plants: organic nitrogen use and availability in terrestrial ecosystems. Oecologia 128:305-316

Lipson DA, Schmidt SK, Monson RK (1999) Links between microbial population dynamics and nitrogen availability in an alpine ecosystem. Ecology 80:1623-1631

McFarland JW, Ruess RW, Kielland K, Doyle AP (2002) Cycling dynamics of $\mathrm{NH}_{4}^{+}$and amino acid nitrogen in soils of a deciduous boreal forest ecosystem. Ecosystems 5:775-788

McKane RB, Johnson LC, Shaver GR, Nadelhoffer KJ, Rastetter EB, Fry B, Giblin AE, Kielland K, Kwiatkowski BL, Laundre JA, Murray G (2002) Resource-based niches provide a basis for plant species diversity and dominance in arctic tundra. Nature 415:6871

Michelsen A, Quarmby C, Sleep D, Jonasson S (1998) Vascular plant ${ }^{15} \mathrm{~N}$ natural abundance in heath and forest tundra ecosystems is closely correlated with presence and type of mycorrhizal fungi in roots. Oecologia 115:406-418

Montgomery HJ, Monreal CM, Young JC, Seifert KA (2000) Determination of soil fungal biomass from soil ergosterol analyses. Soil Biol Biochem 32:1207-1217

Näsholm T, Ekblad A, Nordin A, Giesler R, Högberg M, Högberg P (1998) Boreal forest plants take up organic nitrogen. Nature 392:914-916

Nordin A, Högberg P, Näsholm T (2001) Soil nitrogen form and plant nitrogen uptake along a boreal forest productivity gradient. Oecologia 129:125-132 
Nordin A, Schmidt IK, Shaver GR (2004) Nitrogen uptake by arctic soil microbes and plants in relation to soil nitrogen supply. Ecology 85:955-962

Nylund J-E, Wallander H (1992) Ergosterol analysis as a means of quantifying mycorrhizal biomass. In: Norris JR, Read DJ, Varma AK (eds) Methods in microbiology, vol 24. Academic Press, London, pp 77-88

Perez-Moreno J, Read DJ (2000) Mobilization and transfer of nutrients from litter to tree seedlings via the vegetative mycelium of ectomycorrhizal plants. New Phytol 145:301-309

Persson J, Högberg P, Ekblad A, Högberg MN, Nordgren A, Näsholm $\mathrm{T}$ (2003) Nitrogen acquisition from inorganic and organic sources by boreal forest plants in the field. Oecologia 137:252 257

Ryan MC, Aravena R (1994) Combining C-13 natural-abundance and fumigation extraction methods to investigate soil microbial biomass turnover. Soil Biol Biochem 26:1583-1585

Salmanowicz WE, Nylund J-E (1988) High performance liquid chromatography determination of ergosterol as a measure of ectomycorrhizal infection in Scots pine. Eur J For Pathol 18:291-298

Schimel JP, Bennett J (2004) Nitrogen mineralization: challenges of a changing paradigm. Ecology 85:591-602

Schimel JP, Chapin III FS (1996) Tundra plant uptake of amino acid and $\mathrm{NH}_{4}^{+}$nitrogen in situ: plants compete well for amino acid $\mathrm{N}$. Ecology 77:2142-2147

Schmidt IK, Jonasson S, Shaver GR, Michelsen A, Nordin A (2002) Mineralization and distribution of nutrients in plants and microbes in four arctic ecosystems: responses to warming. Plant Soil 242:93-106

Simard SW, Durall DM (2004) Mycorrhizal networks: a review of their extent, function, and importance. Can J Bot 82:1140-1165

Smith SE, Read DJ (1997) Mycorrhizal symbiosis. Academic Press, London, UK
Stark JM, Hart SC (1996) Diffusion technique for preparing salt solutions, Kjeldahl digests, and persulfate digests for nitrogen-15 analysis. Soil Sci Soc Am J 60:1846-1855

Stark JM, Hart SC (1997) High rates of nitrification and nitrate turnover in undisturbed coniferous forests. Nature 385:61-64

Svennerstam H, Ganeteg U, Bellini C, Näsholm T (2007) Comprehensive screening of Arabidopsis mutants suggests the lysine histidine transporter 1 to be involved in plant uptake of amino acids. Plant Physiol 143:1853-1860

Taylor AFS, Gebauer G, Read DJ (2004) Uptake of nitrogen and carbon from double-labelled $(\mathrm{N}-15$ and $\mathrm{C}-13)$ glycine by mycorrhizal pine seedlings. New Phytol 164:383-388

van der Heijden EW, Vosatka M (1999) Mycorrhizal associations of Salix repens L. communities in succession of dune ecosystems. II. Mycorrhizal dynamics and interactions of ectomycorrhizal and arbuscular mycorrhizal fungi. Can J Bot 77:1833-1841

Vance ED, Brookes PC, Jenkinson DS (1987) An extraction method for measuring soil microbial biomass-C. Soil Biol Biochem 19:703-707

Vinolas LC, Healey JR, Jones DL (2001) Kinetics of soil microbial uptake of free amino acids. Biol Fert Soils 33:67-74

Wallander H, Arnebrant K, Ostrand F, Kårén O (1997) Uptake of N15-labelled alanine, ammonium and nitrate in Pinus sylvestris $\mathrm{L}$. ectomycorrhiza growing in forest soil treated with nitrogen, sulphur or lime. Plant Soil 195:329-338

Wallander H, Nilsson LO, Hagerberg D, Baath E (2001) Estimation of the biomass and seasonal growth of external mycelium of ectomycorrhizal fungi in the field. New Phytol 151:753-760

Weintraub MN, Schimel JP (2005) Nitrogen cycling and the spread of shrubs control changes in the carbon balance of arctic tundra ecosystems. Bioscience 55:408-415

Zhou JB, Chen ZJ, Li SX (2003) Oxidation efficiency of different oxidants of persulfate method used to determine total nitrogen and phosphorus in solutions. Commun Soil Sci Plan 34:725-734 